\title{
On the presence of fertile gametophytes of Padina pavonica (Dictyotales, Phaeophyceae) from the Iberian coasts
}

\author{
by \\ Amelia Gómez Garreta, Jordi Rull Lluch, M. Carme Barceló Martí \& M. Antonia Ribera Siguan \\ Laboratori de Botànica, Facultat de Farmàcia, Universitat de Barcelona, Av. Joan XXIII s/n, 08028 Barcelona, Spain. \\ ameliagomez@ub.edu (corresponding author),jordirull@ub.edu, mbarcelo@ub.edu, riberasiguan@ub.edu
}

\begin{abstract}
Gómez Garreta, A., Rull Lluch, J., Barceló Martí, M.C. \& Ribera Siguan, M.A. 2007. On the presence of fertile gametophytes of Padina pavonica (Dictyotales, Phaeophyceae) from the Iberian coasts. Anales Jard. Bot. Madrid 64(1): 27-33.

The gametophytes of Padina pavonica (L.) Thivy have received little attention in literature. Both female and predominantly male monoecious gametophytes of $P$. pavonica are recorded for the first time in the Iberian Peninsula. A detailed description of the morphology and the disposition of oogonia and antheridia is presented. In addition, a comparison with literature data on this and other Padina species is carried out.
\end{abstract}

Keywords: Antheridia, oogonia, reproductive structures, algae.

\section{Introduction}

In the last century it was established that Dictyotales have an isomorphic haplodiplontic life history with an alternation between haploid gametophytes and diploid sporophytes (Gaillard, 1972). This pattern of life history was initially hypothesized by Williams (1904) as a result of his studies on Dictyota dichotoma (Hudson) Lamouroux and later stated by Hoyt (1910) in this species and by Wolfe (1918-1919) in Padina vickersiae Hoyt; subsequently, it was accepted for all the taxa of the Dictyotales order.

In many species of Dictyotales, sexual plants are much rarer than sporophytes and, in some cases, they are unknown (Womersley, 1987). In Lybia, Nizamuddin (1981) only found sexual plants in some Dictyopteris and Dictyota species, but not in Padina pavonica. On the other hand, Allender \& Kraft (1983) stud-

\section{Resumen}

Gómez Garreta, A., Rull Lluch, J., Barceló Martí, M.C. \& Ribera Siguan, M.A. 2007. Sobre la presencia de gametófitos fértiles de Padina pavonica (Dictyotales, Phaeophyceae) en las costas ibéricas. Anales Jard. Bot. Madrid 64(1): 27-33 (en inglés).

Los gametófitos de Padina pavonica (L.) Thivy han sido escasamente reseñados en la bibliografía. En este trabajo se señala por primera vez en las costas de la Península Ibérica la presencia de gametófitos fértiles de $P$. pavonica, tanto femeninos como monoicos predominantemente masculinos. Se presenta una detallada descripción de la disposición y la morfología de los oogonios y anteridios. Asimismo, se realiza una comparación con los datos bibliográficos de esta especie y con los de otras especies de Padina.

Palabras clave: Anteridios, oogonios, estructuras reproductoras, algas.

ied 22 Dictyotales taxa from Lord Howe Island (New South Wales) but only observed sexual structures in a few specimens of Zonaria diesingiana J. Agardh (male), Padina tenuis Bory (female), Padina crassa Yamada (female) and Spatoglossum macrodontum J. Agardh (male). In the phenological study of 8 Dictyotales taxa on Majorca Island, including P. pavonica, Gómez Garreta (1983) did not find antheridia in any species and only observed oogonia in $D$. dichotoma and D. spiralis Montagne [as Dilophus ligulatus (Kütz.) Feldmann]. In the study of Dictyotales from Sydney Harbour, King \& Farrant (1987) pointed out that the reproduction of the species of this group was almost entirely by means of sporangia, with sexual reproduction being very rare. An exception was in $D$. dichotoma, in which oogonia and anteridia were common throughout the year, both reproductive structures were absent in August and November and an- 
teridia in January and December. In Sydney Harbour, fertile gametophytes of $P$. crassa and P. tenuis were absent all year round, whereas the sporophytes were frequent. In the marine algae flora of Hawaii, Abbott \& Huisman (2004) only reported fertile gametophytes in 4 species of Dictyota from a total of 23 Dictyotales taxa, including 7 Padina species.

Apart from Padina pavonica, data on fertile gametophytes have been published for other Padina species such as: P. australis Hauck, P. boergesenii Allender \& Kraft, $P$. boryana Thivy, P. crassa Yamada, $P$. durvillei Bory, $P$. fraseri Greville, P. gymnospora (Kütz.) Sonder, P. mexicana Dawson, P. sanctae-crucis Boergesen, P. tenuis Bory (= P. boryana, see Wynne, 1998), P. tetrastromatica Hauck ( $=$ P. antillarum (Kützing) Piccone according to Wynne, 1998) and P. vickersiae Hoyt (= P. gymnospora according to Wynne, 1998). The majority of the information about these species refers to the placement of oogonia and antheridia on the plant and the monoecious or dioecious nature of the species (Taylor, 1960; Chapman, 1963; Dawson \& al., 1964; Ramon \& Friedmann, 1966; Gaillard, 1967, 1975; Earle, 1969; Fagerberg \& Dawes, 1973; Allender \& Kraft, 1983; Lawson \& John, 1987; Phillips, 1988; Trono, 1997; Wynne \& De Clerck, 1999; Littler \& Littler, 2000; Abbott \& Huisman, 2004).

Padina pavonica is a widely distributed warm-temperate species (Guiry \& al., 2006). Despite its wide distribution, reports of fertile gametophytes are rare and descriptions of their sexual reproductive structures are scarce and almost exclusively from the Mediterranean Sea (Price \& al., 1979). Reinke (1877) was the first author to report the presence of fertile gametophytes from the Bay of Naples. Funk (1955) only cited 4 gametophytes in a sampling of 1925 in spite of having collected material in the Bay of Naples for many years. In the Banyuls region, Gaillard (1972) found up to $7 \%$ of gametophytes. In Morocco, Gayral (1958) indicated that gametophytes were very rare. Ramon (1969) reported the presence of a small number of gametophytic plants on the coasts of Israel. Only in the Bay of Naples, Ramon \& Friedmann (1966) and Ramon (1969) pointed out a considerable number of gametophytes with an exceptional $50 \%$ of gametophytes in a unique population. On the European Atlantic coasts, Williams (1905) detected very few sexual plants in Dorset and Devon (English coasts). Also on the English coasts, Carter (1927) reported no fertile gametophytes out of several hundred specimens collected throughout two summers. On the coasts of French Brittany, Gaillard (1972) found only one gametophyte out of 300 tetrasporophytes. For the rest of the distribution area, references to gametophytes are very scarce and correspond principally to the Caribbean zone (Taylor, 1960; Littler \& Littler, 2000).

Concerning the descriptions of Padina pavonica gametophytic plants, Reinke (1878) provided the first description of sexual reproductive structures. Hamel (1939) published a short description and illustrated the oogonia and antheridia from material from the French coasts. Taylor (1960) and Littler \& Littler (2000) reported a brief description of Caribbean gametophytic specimens. Ramon \& Friedmann (1966) published the most complete study on the gametophytes of Mediterranean Padina species, including the sex distribution rate and disposition of sexual structures, but adding little data on the morphology of the oogonia and antheridia.

Padina pavonica is a very common species in the Iberian Peninsula, both on the Atlantic and Mediterranean coasts including those of the Balearic Islands (Barceló \& al., 1998). However, a review of the literature about the Iberian Peninsula algal flora has revealed the absence of references to $P$. pavonica gametophytes.

During the revision of the Order Dictyotales concerning the "Flora phycologica iberica", we carried out an exhaustive sampling of Padina pavonica along the Iberian Peninsula and the Balearic Islands coasts between the years 1991-2004, with a total of 90 specimens. This material is held at the BCN-Phyc. (herbarium of the Plant Biodiversity Documentation Centre of the University of Barcelona). In addition, previous material of this species kept in the same herbarium was revised (51 sheets). Although fertile sporophytic plants were frequent, fertile gametophytes were never observed. Similarly, the revision of 82 Iberian specimens of $P$. pavonica from other European herbaria (HGI-A, MGC-Phyc, MUB, PC, SANT-Algae, VABPhyc, and the private herbaria of Aurelio Aranda, Enric Balleteros and Tomás Gallardo), showed the apparent absence of fertile gametophytes on Iberian coasts.

On March 2005, fertile gametophytes of Padina pavonica were collected in the Spanish Mediterranean coasts (Girona). This first observation of fertile gametophytes of this species induced us to study these little known sexual structures in order to obtain a detailed description of their morphology and position on the plant, as well as their monoecious/dioecious character.

\section{Material and methods}

On 20 March 2005 a few fertile gametophytes of Padina pavonica were collected from the upper infralittoral (10-50 cm depth) in Cala Santa Cristina (Lloret de 
Mar, Girona, Spain). In order to check the presence of fertile gametophytes and to calculate the ratio of fertile gametophytes, fertile sporophytes and sterile plants, 50 specimens of $P$. pavonica were sampled from the same population during the following months. In the first sampling, on 3 April 2005, fertile gametophytes were found but in the second, on 4 May 2005, fertile gametophytes were not observed. These specimens have been deposited in the BCN-Phyc. herbarium (Cala Santa Cristina, Girona, Spain, 20-03-2005, predominantly male monoecious gametophyte, BCN-Phyc. 2735; ibid., 20-03-2005, sporophyte, BCN-Phyc 2736; ibid., 03-04-2005, sporophyte, BCN-Phyc. 2737; ibid., 03-04-2005, predominantly male monoecious gametophyte, BCN-Phyc. 2738; ibid., 03-04-2005, female dioecious gametophyte, BCN-Phyc. 2739; ibid., 04-052005, sporophyte, BCN-Phyc. 2740).

Our observations are based on fresh specimens preserved in $4 \%$ formalin-seawater. Sections of the specimens were made by hand with a razor blade and studied under a light microscope. The reproductive structures were drawn with a camera lucida incorporated into the microscope or they were photographed.

\section{Results}

Fertile gametophytes of Padina pavonica were only observed in Santa Cristina on 20 March and 3 April 2005. Of the 50 specimens sampled in April, 38 were tetrasporophytes $(75 \%)$ and 12 were gametophytes $(25 \%)$. Of the latter, 7 were female gametophytes and 5 monoecious gametophytes which were predominantly male. Strictly male gametophytes as well as monoecious gametophytes which were predominantly female were never observed.

In both dioecious and monoecious plants, gametangia were arranged in sori situated in parallel bands on both sides of the concentric hair lines. The sori were always situated on the lower surface of the frond usually uncalcified. The sori tended to spread and join together, forming a more or less dark continuous belt. The two bands of gametangial sori per hair line usually had different widths, the upper band (290-1350 $\mu \mathrm{m})$ being wider than the lower one (230$650 \mu \mathrm{m}$ ); usually the maximum width values of the bands correspond to the basal part of the plant.

In female gametophytes, the oogonial sori were rectangular-oblong in surface view and they were situat-
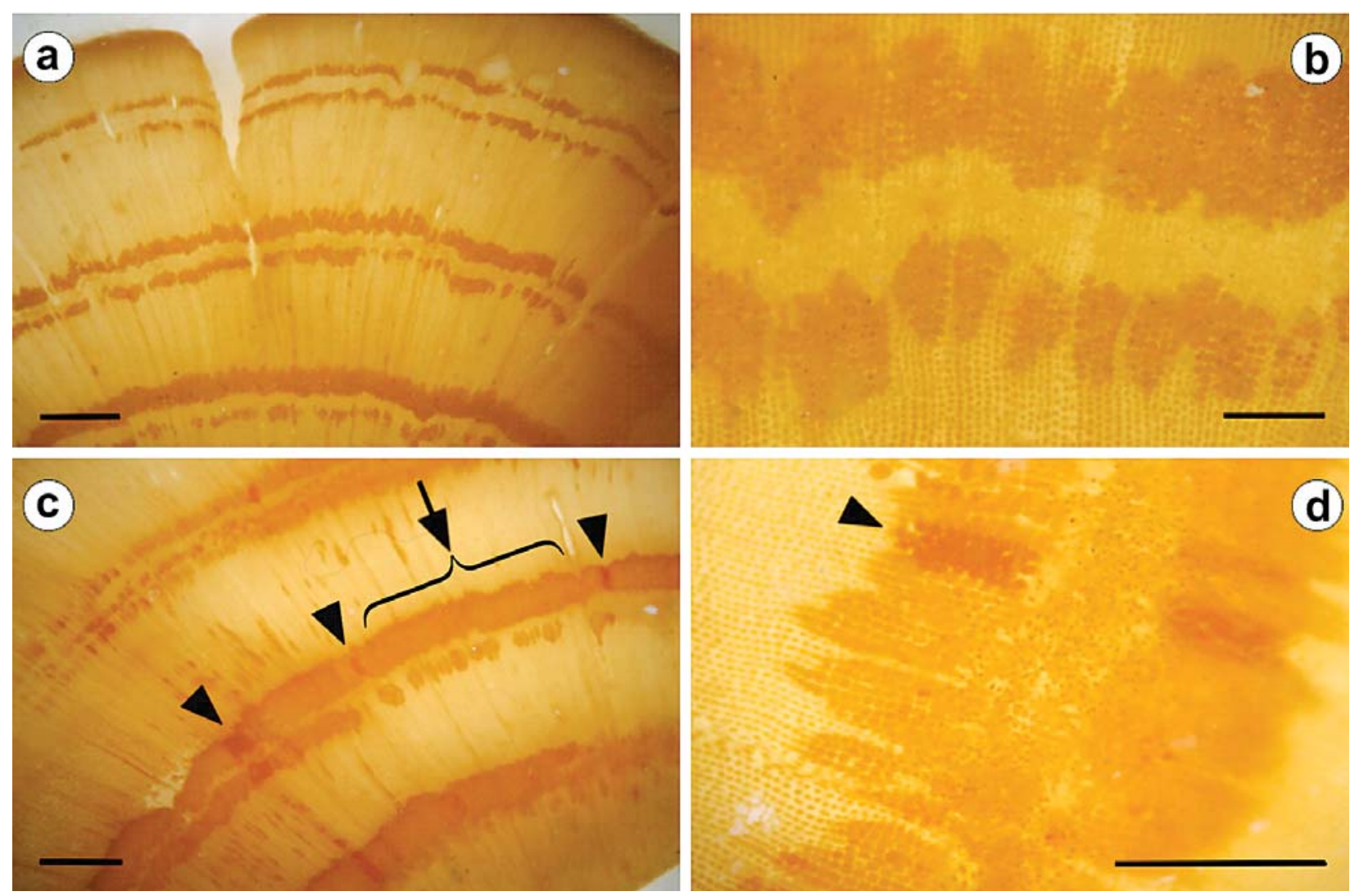

Fig. 1. Padina pavonica: a, b, female gametophytes with oogonial sori in surface view (BCN-Phyc. 2739); c, d, predominantly male gametophytes in surface view (BCN-Phyc. 2738) showing antheridial sori (arrow) and small oogonial sori (arrow heads). Scale bars: $\mathrm{a}, \mathrm{c}=2 \mathrm{~mm} ; \mathrm{b}, \mathrm{d}=400 \mu \mathrm{m}$. 
ed perpendicularly to the hair lines (Fig. 1 a). The sori were formed by a variable number of parallel rows with 8-18 oogonia per row (Fig. 1 b). In surface view, the oogonia were rounded to ovoid, measuring 44-78 $\times 39-50 \mu \mathrm{m}$; in radial section, they were ovoid and measured 78-178 × 39-72 um (Fig. 2 a, e).

In monoecious specimens, the gametangial bands were formed mainly by male sori that alternate with occasional female sori of only 1-4 rows of oogonia (Figs $1 \mathrm{c}, \mathrm{d}, 2 \mathrm{~b}$ ). The male sori were formed by rows of 8-22 (30) antheridia and the female by 8-10 oogonia per row (Figs $1 \mathrm{~d}, 2 \mathrm{~b}$ ). In surface view, the antheridia were ovoid or rectangular, 39-72 $\times 28-44 \mu \mathrm{m}$. In radial section they were rectangular, 39-78 $\times 28-50 \mu \mathrm{m}$ (Fig. 2 c), although the mature antheridia, situated in the basal part of the plants, were pyriform and measured $122-183 \times 50-72 \mu \mathrm{m}$.

Oogonia and antheridia were originated by division of cortical cells in a plane parallel to the surface of the blade. The first division gives rise to a small supporting cell and the reproductive structures (Fig. $2 \mathrm{~d}$ ). In the formation of the oogonia, a second and sometimes a third transversal division can occur, and a pedicel, 1-3 cells, may be formed (Fig. 2 e). Both oogonia and antheridia are covered by a thick indusium (Fig. 2 d, e).

\section{Discussion}

The low rate of Padina pavonica gametophytes in comparison with sporophytes found in the Santa

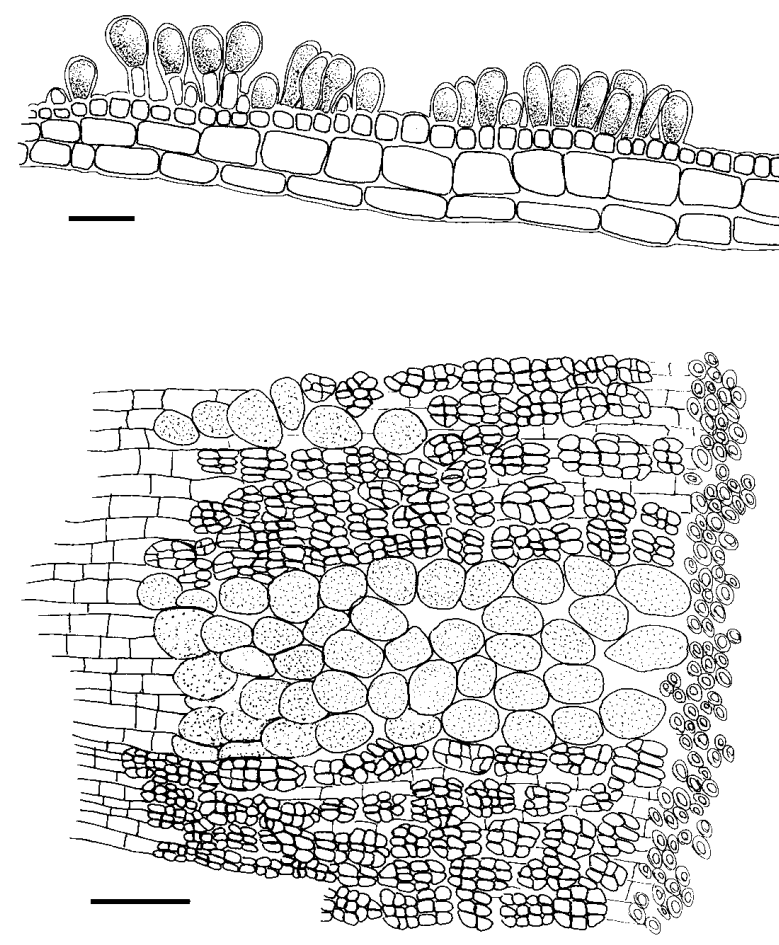

b
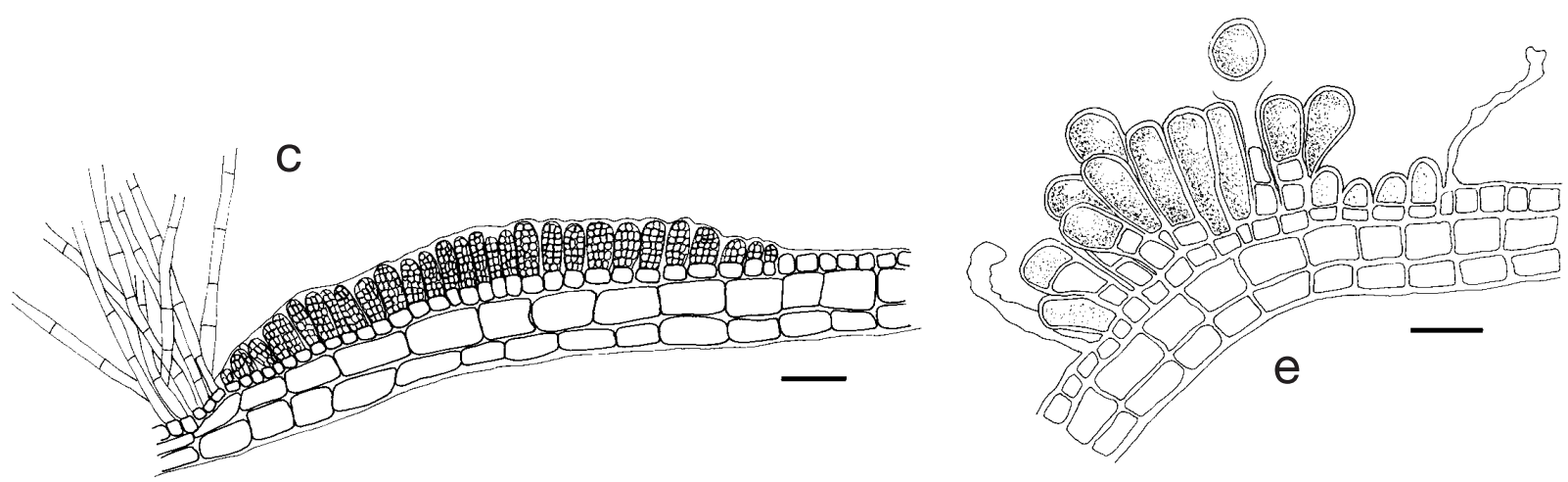

Fig. 2. Padina pavonica: $\mathbf{a}$, oogonial sori in radial section; $\mathbf{b}$, antheridial and oogonial sori in surface view; $\mathbf{c}$, antheridial sorus in radial section; $\mathbf{d}$, young oogonial sorus in radial section; e, mature oogonial sorus in radial section. (a, d, e: BCN-Phyc. 2739; b, c: BCN-Phyc. 2738). Scale bars: a-e $=100 \mu \mathrm{m}$. 
Cristina population agrees with the literature data. Gaillard (1972) did culture experiments with tetrasporophytic plants from the French Atlantic coast (Dinard) and the French Mediterranean coast (Banyuls); after 12-15 months this author obtained fertile specimens which all were tetrasporophytes plants. For this reason Gaillard concluded that a supplementary cycle exclusively tetrasporophytic occurs, which is inserted into the normal haplodiplontic life cycle and even seems to replace it in many areas. In that context, she suggested that apomeiosis may occur in the mother cells of the tetraspores, resulting in meiosis being very rare. The frequency of the apomeiosis process could explain the dominant tendency of sporophytes over gametophytes in the majority of geographical areas. Thus, Gaillard (1972) pointed out that, in some regions, the ecological conditions could explain the abundance of tetrasporophytes over gametophytes, but this author did not indicate which conditions were favorable to the development of each generation and to stimulate the tetrasporophytic life history commented on previously. Price \& al. (1979) indicated that in the Mediterranean Sea the higher temperatures and levels of illumination lead to generally more abundant and perennial populations. This probably entails a more continuous sequence of individual growth and degeneration, perhaps with gametangial formation, than in the Atlantic coasts. The only reference to seasonality of gametophytes is given by Ramon \& Friedmann (1966), who found gametophytes in summer and autumn (July, September and October). This does not agree with our observations, since we only found gametophytes in Santa Cristina in spring (March, April). The scarcity of data on the presence of gametophytes does not allow us to obtain conclusions concerning the phenology of this species.

In the genus Padina, several species are considered as dioecious and a small number as monoecious. However, in many cases the gametophytes are unknown so it is not possible to know if the plants are monoecious or dioecious. Species cited as dioecious plants are P. boryana (Abbott \& Huisman, 2004), P. fraseri (Phillips, 1988), P. gymnospora [Taylor, 1960; Chapman, 1963 (as P. vickersiae); Ramon \& Friedmann, 1966; Earle, 1969; Fagerberg \& Dawes, 1973 (as P. vickersiae) ], P. sanctae-crucis (Gaillard, 1975; Earle, 1969; Taylor, 1960; Littler \& Littler, 2000) and P. antillarum (Gaillard, 1967, as P. tetrastromatica). On the other hand, P. australis (Lawson \& John, 1987; Abbott \& Huisman, 2004) and P. mexicana (Lawson $\&$ John, 1987) are monoecious species. Concerning $P$. pavonica, several authors point out that it can behave as either monoecious or dioecious. Reinke (1878) and Funk (1955) found monoecious gametophytes for P. pavonica, and Taylor (1960) and Littler \& Littler (2000) also cited plants with antheridia alternating with oogonia in the Caribbean Sea. Similarly, Hamel (1939) described monoecious gametophytes from the French Mediterranean coasts, but he pointed out that the abundance of the male and female structures was unequal, since his specimens were predominantly female with numerous oogonial sori alternating with few antheridial sori. However, he did not mention when the fertile specimes were collected. Finally, Ramon \& Friedmann (1966) cited four types of P. pavonica gametophytes: monoecious bisexual, monoecious predominantly male, dioecious female and dioecious male for different locations in the Bay of Naples. These authors were the only ones that pointed out the existence of dioecious gametophytes of $P$. pavonica occurring in considerable numbers in some populations and seasons of the year. The abundance of each type of gametophyte in different populations studied throughout the year allowed Ramon \& Friedmann (1966) to propose that their presence is related to ecological factors, principally the season and the depth, which determines the water temperature. The most important factor is the water temperature at the time of the early development of gametophytes. At higher water temperatures, the gametophytes tend to be dioecious, while lower water temperatures apparently increase the ratio of monoecism. In any case, Price \& al. (1979) pointed out that the situation is probably not quite as straightforward as indicated by Ramon \& Friedmann (1966), because some aspects of light levels also are involved, as they are in $P$. sanctae-crucis (Allender, 1977, as P. japonica). In our population, in shallow water and in spring, we found female gametophytes (7 specimens) and monoecious gametophytes predominantly male ( 5 specimens) at the same time. However, our results from a single sample do not allow us to conclude if they agree or not with Ramon and Friedmann's hypothesis.

In our Mediterranean Iberian plants we observed no morphological and anatomical differences between the thallus of female gametophytes and monoecious gametophytes. Concerning this aspect, we did not find any references for Padina pavonica. However, in P. antillarum (as P. tetrastromatica) from the coasts of the Philippines, Trono (1997) pointed out that male plants in general are smaller in size, paler and less lobed than the female plants.

The disposition of the gametangia sori in concentric and more or less continuous bands on each side of the hair lines observed is in agreement with the litera- 
ture. Taylor (1960) and Ramon \& Friedmann (1966) pointed out that sometimes the lower band is less developed than the upper one or even entirely absent, as was observed in our specimens. On the other hand, we always observed the gametangial sori on the lower surface of the thallus which agrees with the observations of Taylor (1960). In contrast, Ramon \& Friedmann (1966) indicated that, although gametangial sori are usually only on one side, they can occasionally be on both sides. And finally, the presence of an indusium covering both antheridial and oogonial sori, as observed in our specimens, was only cited by Ramon \& Friedmann (1966).

Concerning the shape and size of gametangia, different authors (Hamel, 1939; Taylor, 1960; Littler \& Littler, 2000) agree that the oogonia are spherical and measure 40-50 $\mu \mathrm{m}$ in diameter, in surface view. These observations agree more or less with our data: oogonia are spherical or ovoid and 44-78 × 39-50 $\mu \mathrm{m}$. Information about the oogonia in radial section is very scarce in the literature. According to Hamel (1939), oogonia have a 2-cell pedicel although we observed some pedicels with 3 cells. Concerning antheridia, Hamel (1939) pointed out that they have unicellular pedicel, as observed in our specimens, and this author included in his paper two pictures in which the antheridia have a size and shape similar to the ones our plants have.

\section{Acknowledgements}

We are grateful to Noemi Salvador and Toni Manghisi for their technical assistance in making photographs and to Tania Grace Johnson for reviewing the English text. This study was supported by the projects PB90-0461-C02-01 and REN2001-1473-C0303/GLO of the Spanish Government.

\section{References}

Abbott, I.A. \& Huisman, J.M. 2004. Marine green and brown algae of the Hawaiian Islands. Bishop Museum Bulletin in Botany 4: $1-259$.

Allender, B.M. 1977. Ecological experimentation with the generations of Padina japonica Yamada (Dictyotales: Phaeophyta). Journal of Experimental Marine Biology and Ecology 26: 225234.

Allender, B.M. \& Kraft, G.T. 1983. The marine algae of Lord Howe Island (New South Wales): the Dictyotales and Cutleriales (Phaeophyta). Brunonia 6: 73-130.

Barceló, M.C., Gómez Garreta, A., Ribera, M.A. \& Rull Lluch, J. 1998. Mapas de distribución de algas marinas de la Península Ibérica e Islas Baleares. XI Lobophora variegata (Lamour.) Womersley, Padina pavonica (L.) Thivy y Zonaria tournefortii (Lamour.) Mont. (Dictyotales, Fucophyceae). Botanica Complutensis 22: 179-186.

Carter, P.W. 1927. The life-history of Padina pavonica I. Structure and cytology of the tetrasporangial Plant. Annals of Botany 41: 139-159.
Chapman, V.J. 1963. The marine algae of Jamaica. Part. 2. Phaeophyceae and Rhodophyceae. Bulletin of the Institute of Jamaica, Science Series 12: 1-201.

Dawson, E.Y., Acleto, C. \& Foldvik, N. 1964. The seaweeds of Peru. Beihefte zur Nova Hedwigia 13: 1-111.

Earle, S.A. 1969. Phaeophyta of Eastern Gulf of Mexico. Phycologia 7: 71-254.

Fagerberg, W.R. \& Dawes, C.J. 1973. An electron microscopic study of the sporophytic and gametophytic plants of Padina vickersiae Hoyt. Journal of Phycology 9: 199-204.

Funk, G. 1955. Beiträge zur Kenntnis der Meeresalgen von Neapel. Pubblicazioni della Stazione Zoologica di Napoli 25 suppl.: 1-178

Gaillard, J. 1967. Étude monographique de Padina tetrastromatica Hauck. Bulletin de l'Institut Fondamental d'Afrique Noire, Série A, Sciences Naturelles 29: 447-463.

Gaillard, J. 1972. Quelques remarques sur le cycle reproducteur des Dictyotales et sur ses variations. Société Botanique de France, Mémoires 1972: 145-150.

Gaillard, J. 1975. Padina sanctae-crucis Boergesen, Padina japonica Yamada, Padina haitiensis Thivy et leurs affinities. Botaniste 57: $85-103$

Gayral, P. 1958. Algues de la côte atlantique marocaine. Vol.1. Edita. Casablanca.

Gómez Garreta, A. 1983. Estudio fenológico de la vegetación marina de la Isla de Mallorca. Tesis Doctorales 39. Universidad Complutense de Madrid.

Guiry, M.D., Rindi, F. \& Guiry, G.M. 2006. AlgaeBase version 4.0. World-wide electronic publication, National University of Ireland, Galway [http://www.algaebase.org].

Hamel, G. 1939. Phéophycées de France. Fasc. 5. Paris.

Hoyt, W.D. 1910. Alternations of generations and sexuality in Dictyota dichotoma. Botanical Gazette 49: 55-57.

King, R.J. \& Farrant, P.A. 1987. The phenology of the Dictyotales (Phaeophyceae) at a sheltered locality in Sydney Harbour, New South Wales, Australia. Botanica Marina 30:341-350.

Lawson, G.W. \& John, D.M. 1987. The marine algae and coastal environment of tropical West Africa. Beihefte zur Nova Hedwigia 93: 1-415.

Littler, D.S. \& Littler, M.M. 2000. Caribbean Reef Plants. Offshore Graphics, Washington.

Nizamuddin, M. 1981. Contribution to the marine algae of Libya: Dictyotales. Bibliotheca Phycologica 54: 1-122.

Phillips, J.A. 1988. Reproduction in Southern Australian species of the Dictyotales (Phaeophyta). Botanica Marina 31: 437-445.

Price, J.M., Tittley, I. \& Richardson, W.D. 1979. The distribution of Padina pavonica (L.) Lamour. (Phaeophyta: Dictyotales) on British and adjacent European shores. Bulletin of the British Museum (Natural History), Botany series 7: 1-67.

Ramon, E. 1969. Studies on the biology of reproduction of the algae Padina pavonica (L.) Thivy and Padina gymnospora (Kütz.) Vickers -Dictyotales- in the Mediterranean Sea. Ph. D. Thesis. The Hebrew University of Jerusalem.

Ramon, E. \& Friedmann, I. 1966. The gametophyte of Padina in the Mediterranean. Proceedings of the International Seaweed Symposium 5: 183-196.

Reinke, J. 1877. Ein paar Bemerkungen über Scheitel-wachstum bei Dictyodaceen [sic!] und Fucaceen. I. Botanische Zeitung 35: 441-446.

Reinke, J. 1878. Entwicklungsgeschichtliche Untersuchungen über die Dictyotaceen des Golfs von Neapel. Nova Acta Academiae Caesareae Leopoldino-Carolinae Germanicae Naturae Curiosorum 40: 1-56.

Taylor, W.R. 1960. Marine algae of the Eastern tropical and subtropical coasts of the Americas. The University of Michigan Press. Ann Arbor. 
Trono, G.C. Jr. 1997. Field guide and atlas of the seaweeds resources of the Philippines. Bookmark. Makati City.

Williams, J.L. 1904. Studies in the Dictyotaceae. II. The cytology of the gametophyte generation. Annals of Botany 18: 183-204.

Williams, J.L. 1905. Studies in the Dictyotaceae. III. Periodicity of the sexual cells in Dictyota dichotoma. Annals of Botany 19:531-560.

Wolfe, J.J. 1918-1919. Alternation and parthenogenesis in Padina. Journal of the Elisha Mitchell Scientific Society 34: 78-109.

Womersley, H.B.S. 1987. The Marine Benthic Flora of Southern Australia, Part II. South Australian Government Printing Division. Adelaide.
Wynne, M.J. 1998. A study of Padina antillarum (Kützing) Piccone and a comparison with P. tetrastromatica Hauck (Dictyotales, Phaeophyta). Cryptogamie, Algologie 19: 271-289.

Wynne, M.J. \& De Clerck, O. 1999. First reports of Padina antillarum and P. glabra (Phaeophyta, Dictyotaceae) from Florida, with a key to the Western Atlantic species of the genus. Caribbean Journal of Science 35: 286-295.

Associate Editor: C. Lado Received: 4-IX-2006 Accepted: 24-I-2007 